\title{
Unusual Foreign Body of Oropharynx
}

\section{Yvette Marie Chantal Gyebre¹, Aboubacar Goueta ${ }^{2}$, Bertin Priva Ouedraogo ${ }^{3}$, Moustapha Sereme ${ }^{3}$, Omar Zamtako', Kampadilemba Ouoba ${ }^{5}$}

${ }^{1}$ Maitre de Conférences Agrégé (MCA), Service ORL et CCF, CHU-YO, Ouagadougou, Burkina Faso

${ }^{2}$ Interne des Hopitaux, DES en ORL, Service ORL et CCF, CHU-YO, Ouagadougou, Burkina Faso

${ }^{3} \mathrm{MCA}$, Service ORL et CCF, CHU-YO, Ouagadougou, Burkina Faso

${ }^{4}$ Medecin, Service ORL et CCF, CHU-YO, Ouagadougou, Burkina Faso

${ }^{5}$ Professeur Titulaire, Service ORL et CCF, CHU-YO, Ouagadougou, Burkina Faso

Email:ycgyebre@gmail.com, egoueta@yahoo.com, Bertin oued@yahoo.fr, serememoustapha@yahoo.fr, ouobakpd@yahoo.fr

How to cite this paper: Gyebre, Y.M.C., Goueta, A., Ouedraogo, B.P., Sereme, M., Zamtako, O. and Ouoba, K. (2016) Unusual Foreign Body of Oropharynx. International Journal of Otolaryngology and Head \& Neck Surgery, 5, 189-194.

http://dx.doi.org/10.4236/ijohns.2016.55030

Received: August 10, 2016

Accepted: September 17, 2016

Published: September 22, 2016

Copyright $\odot 2016$ by authors and Scientific Research Publishing Inc. This work is licensed under the Creative Commons Attribution International License (CC BY 4.0).

http://creativecommons.org/licenses/by/4.0/ (c) (i) Open Access

\section{Abstract}

Introduction: The foreign bodies of the oropharynx are mainly encountered in children. They rarely raise diagnostic problem, but remain a haunting of the CCF and ENT surgeon. Objective: We report a special case of foreign body entering the oropharynx and measuring $15 \mathrm{~cm}$ of long in a boy of 7 years, in order to discuss the diagnostic and therapeutic approach. Observation: A 7 year old male student has been received in emergency for accidental trauma of the oropharynx by a particular object, a pencil. The diagnosis has been essentially clinical. The exhibition of the oropharynx using the open mouth of Boyles Davis has obviously shown the foreign body penetrating the right anterior pillar crossing the parapharyngeal spaces till the right posterolateral prevertebral space. The extraction of the foreign body was done by endoscopic route under general anesthesia. As a remarkable fact, it was the gumming end that was penetrating. The postoperative course was uneventful. Conclusion: This type of foreign body of oropharynx constitutes a medical and surgical emergency. From an easy and positive diagnosis, these foreign bodies especially raise a problem of lesion diagnostic and therapeutic approach. Prevention through education and awareness of all the actors (students, children, parents) remain the pledge of their control.

\section{Keywords}

Foreign Body, Pencil, Oropharynx

\section{Introduction}

The foreign bodies penetrating in the oropharynx are an emergency relatively frequent in children [1]. They rarely raise a problem of positive diagnosis but remain a haunting 
of the CCF and ENT surgeon. Curing it obeys a general rule saying that any foreign body entering through the natural ways must be extracted by the same ways according to Jakson Chevalier quoted by Thiam [1].

We provide an unusual case of foreign body entering the oropharynx which we discuss the diagnostic and therapeutic approach, according to the literature data.

\section{Clinical Case}

A student boy of 7 years old has been received in emergency in the ENT and Neck Facial Surgery department, University Hospital Yalgado Ouedraogo for foreign body of a type of pencil entering the oropharynx.

According to the entourage, the child in a playful accident would have fallen off his bike when he had the pencil of paper in his mouth. This was followed by a fall on his face causing therefore a depression of the object in the pharynx associated with mouth bleeding and hypersalivation without initial loss of consciousness.

The examination revealed a good general condition, a clear conscience and a stable hemodynamic status. He was conscious with a Glasgow 15.

Physically, the examination of the oral cavity and oropharynx could only find a part of the foreign body dilapidated outside the oral cavity (Figure 1) associated with a limited opening the of mouth.

The other part of the foreign body was deeply depressed obliquely in the anterior pillar of the right amygdala with a horizontal bleeding wound situated in the anterior pillar of about $2 \mathrm{~cm}$.

The penetrating end of the pencil was protruding subcutaneously at the level of the right postauricular region (Figure 2(a) and Figure 2(b)), behind the main posterior sterno-mastoid muscle It seems to have passed successively through the right tonsillar region, parapharyngeal, pterygoid and the right paraspinal region.

The remainder of the physical examination was unremarkable. The neurological examination was normal. There was no cervical emphysema or hematoma. The diagnosis of the trauma of the oropharynx caused by a cold weapon was retained.

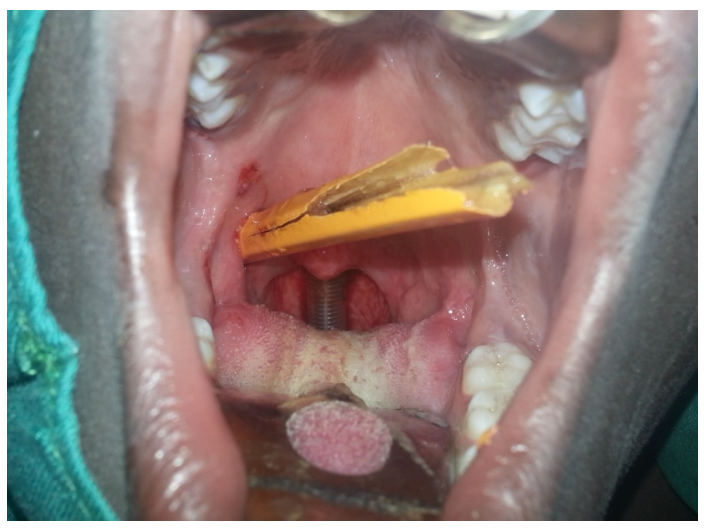

Figure 1. Pencil penetrating the anterior pillar of the right amygdala. 


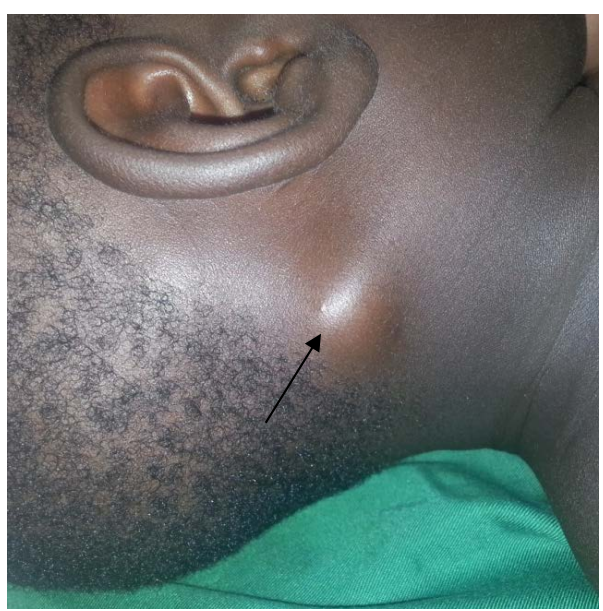

(a)

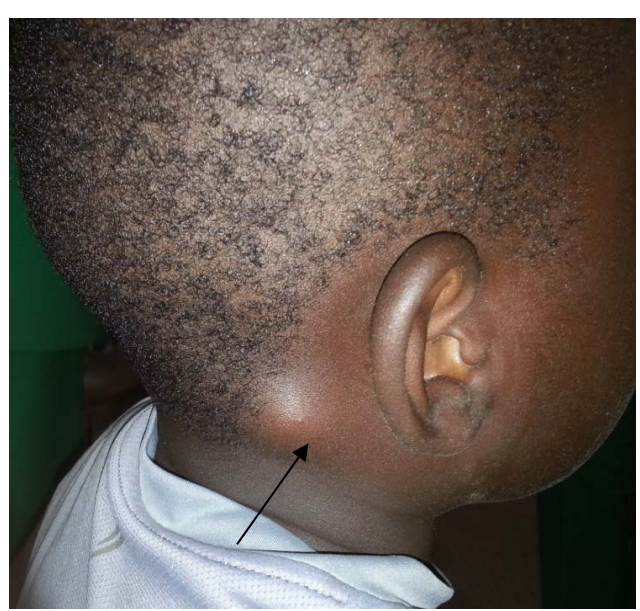

(b)

Figure 2. (a) and (b): Revealing left postauricular tumefaction when palpating the end of the pencil.

In emergency, the extraction of the foreign body was made two hours after the accident by endobuccal way under general anesthesia. Indeed, in its appropriate direction, the pencil was gently removed. It is then found that it is the rounded gumming end that penetrated the pillar. After extraction, we discovered a rounded wound of approximately two (02) centimeters in the right anterior pillar. This penetrating wound in the anterior pillar was not hemorrhagic during examination (Figure 3). It was sutured loosely by two points with absorbable $3 / 0$ thread. The postoperative course was uneventful.

The boy benefited from an additional medical treatment with antibiotic (amoxicillin + clavulanic acid), analgesic (paracetamol), and mouthwash, mouth betadine for 10 days. A control was made 10 days after the wound was healed and the boy was properly fed.

\section{Discussion}

The foreign bodies ENT of the child are of siege and nature varied. They are sometimes visualized by the parents and removed at home as soon as they are introduced in the mouth. If need be, they are often landlocked in the hypopharynx, in the esophagus or the lower airways. Those of the oropharynx are relatively frequent [2]-[4]. The special feature in our case is that the foreign body is a pencil of paper, school use. This is the 2nd and longest foreign body oropharyngeal in the literature after the one submitted by Thiam [1] (Figure 4). In our case it is the rounded and soft gumming end of the pencil, which reveals the violence of the trauma.

The circumstances of occurrences of foreign bodies in the oropharynx are usually evident.

Classically, the children run with objects in their mouth, can fall and suffer from oropharyngeal trauma or a penetrating foreign body of oropharynx [5]: This is the classic pencil injuries of Anglo-Saxons [6]. The most often blunt or sharp objects. The 


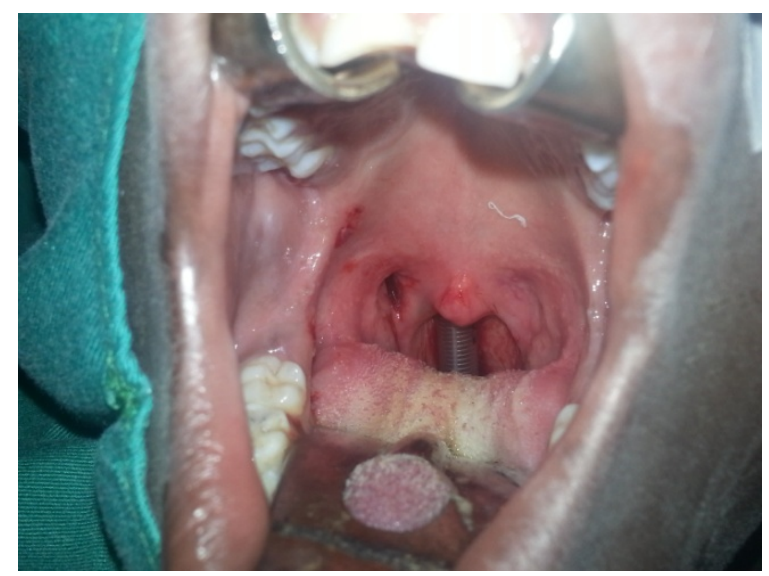

Figure 3. Penetrating wound of the right tonsillar region after extraction of the pencil.

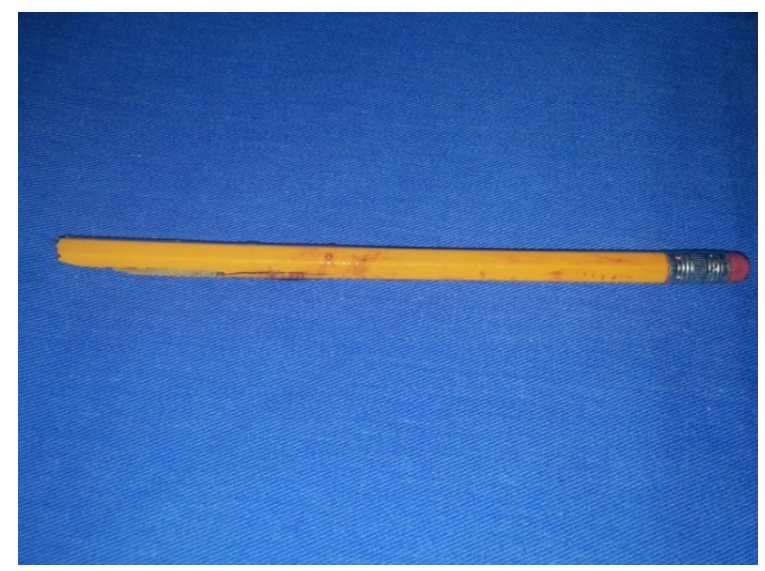

Figure 4. Foreign body of the type of pencil long of $15 \mathrm{~cm}$.

diagnosis of foreign body of oropharynx goes through a good initial clinical examination [7]. The difficulty lies in the lesional diagnostic and therapeutic attitude. Indeed at thelesionplan, there is a potential risk of vascular injury (carotid artery, external jugular vein) or its thrombosis [8]. Other lesions can arise such as nerve and muscle damage (crossing the pterygoid muscles region which would explain the limitation of mouth opening is obvious) or injury to the temporomandibular joint. In order to specify the lesions and the different spaces traversed by the foreign body and look for complications, a computed tomography (CT) cervicofacial would have been the ideal in this case. But it would delay the treatment. Some authors [6] [9] [10] advocate for foreign bodies of small size cervical radiography in search of radiopaque foreign body and complication signs of retropharyngeal emphysema. For Ouoba [7], the endoscopic examination is justified each time the clinical examination is difficult or insufficient.

Our therapeutic approach is debatable. We proceeded to the extraction of the foreign body by removing it quite simply. Not having carried out a TDM, we do not know what was the extent of the injury. Moreover surgical exploration would have been more appropriate and would discover the lesions and proceed with their repair. This simple ex- 
traction could have exposed us to a cataclysmic hemorrhage. The postoperative course was uneventful. However we believe that the optimal therapeutic attitude calls for a complementary balance (TDM) before this gesture. Failing to do so, a surgical exploration as it was the case for Thiam [1] should be practiced. In the literature, two (02) therapeutic attitudes coexist: the e exploratory cervicotomy for penetrating foreign body [1] [9] and the endoscopy or natural route for other types of foreign bodies [10]-[12]. Finally, the two (02) are coupled. The therapeutic approach is based on the type of foreign body and its mechanism. It is noteworthy that in the trauma of the internal carotid artery with blunt object, it will be necessary to wait for 48 hours after the accident, or weeks or even months the appearance of a latero-cervical hematoma, a syndrome ipsilateral Horner and some neurological symptoms (transient ischemic attack, or a focal deficit paresis) [5]. In our patient, after 8 days and after 02 months, we have not noted infectious or neurovascular complications

\section{Conclusion}

The unusual foreign body of oropharynx constitutes a medical and surgical emergency. From a positive diagnosis relatively easy, these foreign bodies raise especially a problem of lesional diagnostic and therapeutic approach. Their potential gravity makes it a concern for the ENT practitioners. Their prevention remains the essential weapon. It goes through education of different stakeholders (students, parents, educators).

\section{References}

[1] Thiam, A., Loum, B., Ndiaye, M., et al. (2012) Corps étranger insolite de l'oropharynx. Médicine d'Afrique Noire. Juin 2012.

[2] Arora, S., Sharma, J.K., Pippal, S.K., et al. (2009) Un corps étranger (pointe de l'aiguille à coudre) inhabituelle dans les amygdales. Brazilian. Journal of Otorhinolaryngology, 75, 908.

[3] Zonfrillo, M.R., Roy, A.D. and Walsh, S.A. (2008) Management of Pediatric Penetring Oropharyngeal Trauma. Pediatric Emergency Care, 24, 172-175.

http://dx.doi.org/10.1097/PEC.0b013e3181669072

[4] Sood, S. and Mether, R. (2007) Intraoral Penetrating Injuries Due to an Unusual Foreign Body. International Journal of Pediatric Otorhinolaryngologyextra, 2, 45-47. http://dx.doi.org/10.1016/j.pedex.2006.12.004

[5] Burkuk, P.K. (2006) Parapharyngeal Space Foreign Body. European Archives of Otorhinolaryngology, 263, 772-774. http://dx.doi.org/10.1007/s00405-006-0068-0

[6] De Beauvillain, M.C. and Malard, O. (1998) Corps étrangers et perforation du pharynx Encyclopédie médicochirurgicale (Elsevier, Paris). Traité d’Oto-rhino-laryngologie. 20-620A-10, 3 p.

[7] Ouoba, K. and Diop, E.M. (1989) Parapharyngeal Space Foreign Body. Dakar Medical, 34, 6-7.

[8] Sagar, S., Kumar, N., Singhal, M., Kumar, S. and Kumar, A. (2010) Un cas rare de la vie en danger les traumatismes pénétrants oropharyngés causée par la brosse à dents dans un enfant. Journal of Indian Society of Pedodontics and Preventive Dentistry, 28, 134-136. http://dx.doi.org/10.4103/0970-4388.66758

[9] Anapha, A.J. and Renuka, A. (2003) A Foreign Body in the Pharynxmigrating throught the 
Internal Jugular Vein. American Journal of Otolaryngology, 24, 89-91.

http://dx.doi.org/10.1053/ajot.2003.20

[10] Doumbia-Singare, K., Timbo, S., Keita, M., Togola-Konipo, F. and Mohamed, A. (2014) Corps étranger du pharynx de découvertefortuite. Mali Médical, Tome XXIV, 3, 66-67.

[11] Incollingo, F. and Shevchenko, Y. (2007) Airway Management in a Child with Penetrating Pharyngeal Wall Foreign Body Injury: A Case Report. American Association of Nurse Anesthetists Journal, 75, 329-331.

[12] Gyébré, Y.M.C., Ouattara, M., E.L.O.L.A., Sérémé, M., Konsem, T., Ouédraogo, P.B., Diallo, O. and Ouoba, K. (2013) Un corps étranger insolite del'œsophage. Journal Tunisie d ORL, 28, 80-82.

Submit or recommend next manuscript to SCIRP and we will provide best service for you:

Accepting pre-submission inquiries through Email, Facebook, LinkedIn, Twitter, etc. A wide selection of journals (inclusive of 9 subjects, more than 200 journals)

Providing 24-hour high-quality service

User-friendly online submission system

Fair and swift peer-review system

Efficient typesetting and proofreading procedure

Display of the result of downloads and visits, as well as the number of cited articles

Maximum dissemination of your research work

Submit your manuscript at: http://papersubmission.scirp.org/

Or contact ijohns@scirp.org 